\title{
The Analysis of Homecare Interest in Pandemic Covid-19 Period Based on Disease Case in Indonesia
}

\author{
C. Nugroho, Suryono, B. Wiseno
}

\section{ABSTRACT}

\begin{abstract}
Homecare as a part of healthcare at home, it can give a freedom for society to get the best healthcare which is appropriate to use. The factor which influences an interest of homecare needs a deep analysis. The aim of this research is for analyzing homecare interest in pandemic covid-19 period based on disease case in Indonesia. This research uses cross-sectional approach. The research population is all of patients in RSUD Pare and the sample is $\mathbf{1 7 2}$ respondents with simple random sampling technique. The data collection is in questionnaire form of homecare interest and disease data of patient, then doing a multivariant analysis of regression linier test. The result of T-Test in each variable where diabetes melitus, innervation case, heart, lungs, fracture, gastrointestinal, and another cases have negative $t$ value with $p$ value $>0,05$ which means there is not any influence to the homecare interest, but in the bladder case has $T$-Test $-2,109$ value ( $p$ value $0,036, \alpha<0,05$ ) which means the bladder case has influence to the homecare interest, such as the post operation case which has $T$-Test 2,112 value ( $p$ value $0,036, \alpha<0,05$ ), it means that the post operation has influence to homecare interest. Someone interest of homecare is not influenced by disease case, except the cases which need more detail care in hospital. Post operation, bladder, and diabetes melitus needs homecare.
\end{abstract}

Keywords: Interest, Homecare, Disease Case.
Published Online: October 27, 2020

ISSN: $2593-8339$

DOI: 10.24018 /ejmed.2020.2.5.524

\section{Nugroho*}

Sekolah Tinggi Ilmu Kesehatan Pamenang, Indonesia.

(e-mail: christiantonug@gmail.com)

Suryono

Sekolah Tinggi Ilmu Kesehatan Pamenang, Indonesia.

(e-mail: suryono.sanjaya@ gmail.com) B. Wiseno

Sekolah Tinggi Ilmu Kesehatan Pamenang, Indonesia.

(e-mail: bambangwiseno72@yahoo.com)

\section{INTRODUCTION}

Homecare is a healthcare at home which is related and comprehensive that is given to the patient or even family's patient to recover, defend, improve their health condition, also optimize independently after getting post medical treatment in hospital [1].

Public hospital in Pare region is RSUD Pare Kediri with the average number of patient: 14514 each year [2]. Based on the data in Pare region that there has not been homecare which is operated consistently, even in private hospital. It is because the lack of strong analysis to the homecare interest in this region.

Depending on RISKESDAS (Riset Kesehatan Dasar or Baseline Health Research) in 2013, the genesis of noncommunicable disease such as hypertension is $25,8 \%$, stroke $12,1 \%$, and diabetes melitus $2,1 \%$ [3]. Disease which needs longer care time becomes callange in nursing world right now, to improve the sustainable supply of nursing services [4]. The sustainable care in this case is transition care, this care function is to manage patient at home, therefore the treatment process is still continuity [5].

Degerative disease which needs relative longer treatment like post stroke patient case which has paralysis complication [6], [7] and needs rehabilitation service that needs relative longer time, furthermore epidemiology transition occurrence which causes chronic disease case is not effective and eficient if it gets a treatment in hospital, accordingly homecare is the way to handle this case [8].

Homecare as one of healthcare is a component of healthcare which is continuous and comprehensive to give to an individual and family in their house with the purpose of improving, defending, recovering health, also maximizing the independence level and minimizing the effect of disease including terminal disease [9].

Looking at a big opportunity of homecare that is known if commonly society needs it, but there is not any homecare operational in Pare region, it will be a big chance for private or even public hospital to establish homecare. Focusing on this case, the researcher analyzed homecare interest in pandemic covid-19 period based on disease case.

\section{METHOD}

The research design is cross-sectional approach. The research population is all of patient in RSUD Pare, and the research sample is 172 respondents with simple random sampling technique on September 2020. The research instrument uses questionnaire which contains of medic diagnosis data and homecare interest of respondents. After collecting data, it is processed and analyzed by using spss 20 , then statistic test of linier regression. 


\section{RESULTS}

TABLE 1: HOMECARE INTEREST BASED ON DISEASE CASE DISSEMINATION

\begin{tabular}{lcccc}
\hline \multirow{2}{*}{ Disease Case } & \multicolumn{3}{c}{ Interest } & \multirow{2}{*}{ Total } \\
\cline { 2 - 4 } & $\begin{array}{c}\text { Very } \\
\text { High }\end{array}$ & High & Medium & \\
\hline Diabetes Melitus & 10 & 17 & 1 & 28 \\
Innervation Case & 5 & 7 & 3 & 15 \\
Bladder Case & 5 & 20 & 1 & 26 \\
Heart Case & 4 & 11 & 0 & 15 \\
Lungs Case & 4 & 4 & 2 & 10 \\
Post Operation Case & 15 & 13 & 1 & 29 \\
Fracture Case & 7 & 6 & 2 & 15 \\
Gastrointestinal & 5 & 12 & 0 & 17 \\
Case & 4 & 12 & 1 & 17 \\
Another Case & 59 & 102 & 11 & 172 \\
Total & & & & \\
\hline
\end{tabular}

Based on data of table 1. in cross tabulation interest depends on client disease case is found that Post operation Case has very high interest about 15 respondents, high 13 respondents, and 1 respondent of medium case, whereas Diabetes Mellitus Case is 10 respondents stated that has very high interest, 17 respondents are high interest, and 1 respondent is medium interest, moreover about Bladder Case has very high interest of 5 respondents, high interest of 20 respondents, and medium interest of 1 respondent.

TABLE 2: THE ANALysis of HoMECARE INTEREST BASED ON DiSEASE CASE

\begin{tabular}{lcccc}
\hline \multirow{2}{*}{ Disease Case } & \multicolumn{4}{c}{ Interest } \\
\cline { 2 - 5 } & $\mathrm{t}(\mathrm{p})$ & Col. (vif) & Sig. & $\mathrm{f}(\mathrm{p})$ \\
\hline Diabetes Melitus & $-1,055$ & 1,646 & 0,293 & \\
Innervation Case & $-1,903$ & 1,385 & 0,059 & \\
Bladder Case & $-2,109$ & 1,610 & 0,036 & \\
Heart Case & $-1,177$ & 1,385 & 0,241 & \\
Lungs Case & $-1,336$ & 1,267 & 0,184 & 0,559 \\
Post Operation Case & 2,112 & 1,000 & 0,036 & \\
Fracture Case & $-0,814$ & 1,385 & 0,417 & \\
Gastrointestinal Case & $-1,070$ & 1,429 & 0,286 & \\
Another Case & $-1,737$ & 1,429 & 0,084 & \\
\hline
\end{tabular}

The result of $\mathrm{f}$ test analysis ( $\mathrm{p}$ value $0,559, \alpha<0,05$ ) which means disease case does not have significant influence to the homecare interest, whereas collinearity analysis shows vif $<10$ value, therefore it can be concluded that disease case does not happen multicollinearity or there is not any strong correlation with homecare interest, similarly $\mathrm{T}$-Test result in each variable where diabetes mellitus, innervation case, heart case, lungs case, fracture, gastrointestinal, and another cases have $t$ negative value with $p$ value $>0,05$ means that there is not any influence to the homecare, but bladder case has T-Test value $-2,109$ ( $p$ value $0,036, \alpha<0,05$ ) means that bladder case has influence to the homecare, similarly post operation case which has $\mathrm{T}$ Test value 2,112 ( $\mathrm{p}$ value $0,036, \alpha<0,05$ ) means that post operation case has influence to the homecare interest.

\section{DISCUSSION}

The research result based on table 1 . above shows that cross tabulation interest depends on client disease case is found that post operation has very high interest about 15 respondents, 13 respondents with high interest, and 1 respondent with medium interest, moreover diabetes melitus case has 10 respondents very high, 17 respondents high, and 1 respondent medium interest, then bladder case has 5 respondents very high, 20 respondents high, and 1 respondent medium interest.

Whereas the result analysis of this research indicates that F-Test is combined with disease case does not give significant influence to the homecare interest, while collinearity analysis shows that it does not occure multicollinearity which means that there is not any strong correlation between disease case and homecare interest [10], moreover the result of $\mathrm{T}$-Test in every variable where diabetes melitus, innervation case, heart case, lungs case, fracture, gastrointestinal, and another cases do not have any influence to the homecare, but bladder case and post operation case have influence to the homecare interest.

Based on this result that the research represents the majority case which is wanted by society about homecare is the case of post operation and diabetes melitus, it happens because commonly post operation patients need more management care at home, which is related to the post-op injury such as an injury which is caused by operation, surgical suture care, injury care [11]. Whilst commonly Diabetes Melitus care in hospital uses the way in giving insulin continously, diabetes injury care with diabetes complication, checking glucose level and consulting nutrient [12].

The most improtant factor of failed controling glucose of diabetes patient is disobedience of patient to the medical treatment [13]. Glucose level which is not controlled well can cause complication which is acute or even chronic, about $63,1 \%$ of diabetes patients in type 2 have risk factor of hypertension complication [14], [15]. Homecare part in managing diabetes can give understanding of medical treatment and obedience of patient to the medical treatment [16].

Whereas the third case is bladder case where the research is found chronic kidney disease, urinary tract infections, cases of patient which the case wants homecare because of chronic kidney disease care, it is about diet and body condition of client that always needs dialysis every week, in fact there is patient who needs dialysis twice in a week [17].

In survey result, Peritoneal Dialysis and Hemodialysis patient are really satisfied to the homecare. Homecare team continously gives social support to the patient [18], [19]. Homecare team also collects information about patient life goals and gives information to them about their dianalysis costs [20].

Prevalence of degerative disease increases such as stroke, diabetes melitus, and another diseases which needs longer medical treatment time and rehabilitation which is relatively save, it makes most of people choose homecare [21]. Homecare is really effective and efficient, because it is able to give chance to another family members to do their daily routine while looking after patient [22]. Beside that the environment around the house is more comfortable for most of patient than hospital, therefore it will hasten their recovery condition [23].

Accordingly the result gives an illustration that someone 
interest of homecare is not influenced by disease case, except the cases which need deep medical treatment in hospital. For instance post operation case and bladder case, it is related to the result in table 1 which indicates the inclination of the case is strong desire to get homecare.

\section{CONCLUSION}

Someone interest of homecare is not influenced by disease case, except the cases which need deep medical treatment in hospital. Post operation, bladder, and diabetes melitus case need homecare.

\section{ACKNOWLEDGMENT}

The writer expresses an advance thanks to Direktorat riset dan Pengabdian Masyarakat DPRM Kemenristek Dikti 2020 and the publict hospital which is located in Pare region that has already given chance in collecting research data in the middle of pandemic covid-19.

\section{REFERENCES}

[1] L. I. E. Kausar, "Pemanfaatan Teknologi Informasi Berbasis Internet Terhadap Perkembangan Home Care Di Indonesia," Din. Kesehat. J. Kebidanan Dan Keperawatan, vol. 10, no. 1, pp. 212-223, 2020, doi: $10.33859 / \mathrm{dksm} . v 10 \mathrm{i} 1.331$.

[2] Dinkes, "Profil Kesehatan Kabupaten Kediri," in Dinkes kabupaten kediri, 2018.

[3] Depkes RI, "Riset Kesehatan Dasar," Jakarta Badan Penelit. dan Pengemb. Kesehat. Kementrian Kesehat. RI, 2013

[4] F. R. Taylor, When west meets east: Is it time for headache medicine to complement "convention" with alternative practices?, vol. 51, no. 7. 2011.

[5] I. S. P. Yuli Lestari, "Telehealth: Elektronik Housecall System, Solusi Mengurangi Biaya Perawatan Kesehatan," J. Keperawatan, vol. XIII, no. 2, pp. 244-248, 2020, doi: 10.31220/osf.io/z5fbp

[6] P. K. Myint, E. F. A. Staufenberg, and K. Sabanathan, "Post-stroke seizure and post-stroke epilepsy," Postgrad. Med. J., vol. 82, no. 971, pp. 568-572, Sep. 2006, doi: 10.1136/pgmj.2005.041426.

[7] S. K. Lui and M. H. Nguyen, "Elderly Stroke Rehabilitation: Overcoming the Complications and Its Associated Challenges," Curr. Gerontol. Geriatr. Res., vol. 2018, p. 9853837, Jun. 2018, doi: 10.1155/2018/9853837.

[8] R. Fahrepi, S. Rate, and A. J. Hadi, "Hubungan Kualitas Pelayanan Homecare dengan tingkat Puskesmas Batua Kota Makassar The Relation Of Home Care Service Quality And Family' s Patient Statisfaction In Batua Public Health Center Jobs Area, Makassar City," Promot. J. Kesehat. Masy., vol. 9, no. 0451, pp. 122-128, 2019, [Online]. Available: https://jurnal.unismuhpalu.ac.id/index.php/PJKM/article/viewFile/58 9/482.

[9] Y. B. Prasetyo, "Homecare Services' Potential at the UMM Hospital: Analysis on the Disease Cases, Public Social and Economy," $J$. Keperawatan, vol. 7, no. 1, pp. 70-78, 2017, doi: 10.22219/jk.v7i1.3921.

[10] W. Yoo, R. Mayberry, S. Bae, K. Singh, Q. Peter He, and J. W. Lillard Jr, "A Study of Effects of MultiCollinearity in the Multivariable Analysis," Int. J. Appl. Sci. Technol., vol. 4, no. 5, pp. 9-19, Oct. 2014, [Online]. Available: https://pubmed.ncbi.nlm.nih.gov/25664257.

[11] K. Yao, L. Bae, and W. P. Yew, "Post-operative wound management," Australian Family Physician, vol. 42, no. 12. pp 867-870, 2013.

[12] “15. Diabetes Care in the Hospital: \&lt;em\&gt;Standards of Medical Care in Diabetes-2019\&lt;/em\&gt;" Diabetes Care, vol. 42, no. Supplement 1, p. S173 LP - S181, Jan. 2019, doi: 10.2337/dc19S015.

[13] J. Casqueiro, J. Casqueiro, and C. Alves, "Infections in patients with diabetes mellitus: A review of pathogenesis," Indian J. Endocrinol.
Metab., vol. 16 Suppl 1, no. Suppl1, pp. S27-S36, Mar. 2012, doi: 10.4103/2230-8210.94253.

[14] R. Chen, B. Ovbiagele, and W. Feng, "Diabetes and Stroke: Epidemiology, Pathophysiology, Pharmaceuticals and Outcomes," Am. J. Med. Sci., vol. 351, no. 4, pp. 380-386, Apr. 2016, doi 10.1016/j.amjms.2016.01.011

[15] Oms, "Global Report on Diabetes," Isbn, vol. 978, pp. 6-86, 2016, [Online].

Available:

http://www.who.int/about/licensing/copyright_form/index.html http://www.who.int/about/licensing/copyright_form/index.html https://apps.who.int/iris/handle/10665/204871 http://www.who.int/about/licensing/.

[16] N. . Suryani, I. M. a. . Wirasuta, and N. M. . Susanti, "Pengaruh Konseling Obat Dalam Home Care Terhadap Kepatuhan Pasien Diabetes Tipe 2 Dengan Komplikasi Hipertensi," J. Farm. Udayana, pp. 6-12, 2013

[17] M. Mallappallil, E. A. Friedman, B. G. Delano, S. I. McFarlane, and M. O. Salifu, "Chronic kidney disease in the elderly: evaluation and management," Clin. Pract. (Lond)., vol. 11, no. 5, pp. 525-535, 2014, doi: $10.2217 / \mathrm{cpr} .14 .46$.

[18] K. Hautsalo, A. Rantanen, and P. Astedt-Kurki, "Family functioning, health and social support assessed by aged home care clients and their family members," J. Clin. Nurs., vol. 22, Dec. 2012, doi: 10.1111/j.1365-2702.2012.04335.x.

[19] A. Babiker et al., "Health care professional development: Working as a team to improve patient care," Sudan. J. Paediatr., vol. 14, no. 2, pp. 9-16, 2014, [Online]. Available: https://pubmed.ncbi.nlm.nih.gov/27493399.

[20] A. S.K., K. P., D. O., and L. a., "Chronic kidney disease and support provided by home care services: A systematic review," $B M C$ Nephrol., vol. 15, no. 1, 2014, [Online]. Available: http://www.embase.com/search/results?subaction=viewrecord\&from =export\&id=L600010605 \nhttp://dx.doi.org/10.1186/1471-2369-15118.

[21] N. N. Tun, G. Arunagirinathan, S. K. Munshi, and J. M. Pappachan "Diabetes mellitus and stroke: A clinical update," World J. Diabetes, vol. 8, no. 6, pp. 235-248, Jun. 2017, doi: 10.4239/wjd.v8.i6.235.

[22] C. H. Ellenbecker, L. Samia, M. J. Cushman, and K. Alster, "Patient Safety and Quality in Home Health Care," Patient Saf. Qual. An Evidence-Based Handb. Nurses, 2008, [Online]. Available: http://www.ncbi.nlm.nih.gov/pubmed/21328733.

[23] W. D. M. S. A. Ma'mur, "Evaluasi Program Homecare Pada Puskesmas Bara- Baraya Kota Makassar," J. Adminitrasi Negara vol. 25, no. 2, pp. 212-228, 2019, doi https://doi.org/10.33509/jan.v25i3.889.

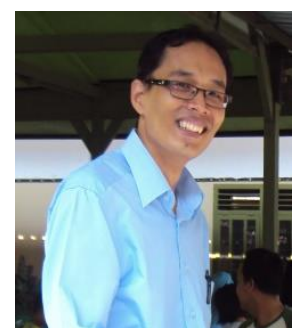

C. Nugroho was born in kediri,East Java, Indonesia (April 19,1979). Airlangga University Nursing graduate (2006) and graduate of Master of Nursing at Airlangga University (2015)

$\mathrm{He}$ is Currently working as a lecturer at Pamenang College of Health Sciences, Pare, kediri, East Java , indonesia. To quota some of his remarkeble publication:

[1] S. Suryono, C. Nugroho, R. H., Java, E., \& Java, E. (2020). Nurser ' S Perspective On Indonesian Nursing Diagnosis Standards: Analysis Study Of Nurses Competence In. solidstatetechnology.us/index.php/JSST/article/view/1330. 